\title{
Ecological studies on diversity of Herpetofauna in Asir region, Kingdom of
} Saudi Arabia.

\author{
Mostafa Fathy Masood ${ }^{1 \& 2 *}$ and Ahmed Ali Asiry ${ }^{1}$ \\ 1-Department of biology, Faculty of Science, Jazan University, Kingdom of Saudi Arabia \\ 2- Department of Zoology, Faculty of Science, Al Azhar University (Assiut-Egypt) \\ *Email: m_f_masood@yahoo.com
}

\section{ABSTRACT}

Conservation of the biological diversity and sustainable use of the resources of earth are enshrined in Islamic low and principles. It is therefore fitting that in 2001 the kingdom of Saudi Arabia became a signatory to the Convention of Conservation on Biological Diversity that seeks to ensure the conservation of species and their habitats for all time.

The study was carried out in Asir region, located in the southwest of the country. Topography and biotic elements of the environment were described. The study area is one of the richest regions of the Kingdom in the diversity of animals, where the region is characterized by the presence of a large group of wild animals belonging to different animal families. In this work, diversity of herpetofauna which found in the region was studied.

Seven species of tailless amphibians (Anura) were recorded, belonging to three families, firstly Bufonidae which include four species, Bufo tihamicus, $B$. dhufarensis, B. arabicus and B. viridis, secondly Hylidae represented by only one species, a tree frog Hyla savignyi, and finally Ranidae represented by two species, Rana ridibunda and Euphlyctis ehrenbergii.

The results showed that there are 38 species of reptiles; 23 species of lizards belonging to the families Gekkonidae, Lacertidae, Scincidae, Agamidae, Varanidae, and Chamaeleontidae and 14 species of snakes belonging to 5 families: Typholopidae, Leptotypholopidae, Colubridae, Elapidae, and Viperidae. Only one species of Turtles, belongs to family Testudinidae, was recorded.

This work was suggested to throw light on the diversity of herpetofauna in Asir region as an important part of the ecosystem that has to be maintained, and to determine species composition of amphibian and reptile communities in different ecosystems as indicators of biodiversity in the study area. It came also to suggest strategies and techniques to determine the abundance of these species.

Key words: Diversity, Survey, Ecology, Conservation, Herpetofauna, Reptiles, Amphibians, Asir, Saudi Arabia.

\section{INTRODUCTION}

Amphibians and reptiles are found on all continents except the Antarctic. Oceans are also inhabited by a few turtles and snakes (Mertens, 1960). They play a very important role in the efforts to conserve biological diversity world-wide. They account for about one quarter of all known vertebrate species. They are important in terms of aesthetic and cultural interest, as well as their significance to science. They also have a great economic value (Mittermeier, et al., 1992). Unfortunately, in conserving the herpetofauna, very significant obstacles may be faced. In particular, many species do not 
have a very positive image in the mind of the general public, mainly because one group of reptiles (snakes) is extremely unpopular with the world at all.

Conservation of the biological diversity and sustainable use of the resources of Earth are enshrined in Islamic low and principles. It is therefore fitting that in 2001 the kingdom of Saudi Arabia became a signatory to the Convention of Conservation on Biological Diversity that seeks to ensure the conservation of species and their habitats for all time (Abuzinada et al., 2004).

The conservation status of animals and plants is one of the most widely used indicators for assessing the condition of ecosystems and their biodiversity. It also provides an important tool in priority-setting exercises for species conservation. At the global level, the best source of information on the conservation status of animals and plants is the IUCN Red List of Threatened Species (IUCN, 2004).

The Kingdom of Saudi Arabia is mostly desert and its geographical location between the temperate and tropical climatic regions, together with the extreme variations in its climatic conditions, make it unique in harboring many species of reptiles. However, very few ecological studies have been undertaken on Saudi Arabian snakes and lizards. Certain authors have described small collections of amphibians and reptiles from different regions in Saudi Arabia, including the Southern Hijaz (Parker, 1933, 1938), Eastern Arabia and Northeastern Arabia (Mandaville, 1965, 1967), Central Arabia (Schmidt, 1941; Al-Wailly \& Al-Uthman, 1971), and Riyadh (Hussein, 1966). Farag and Banaja (1980) identified four anuran species, 28 species of lizards and 15 species of snakes, and mapped their distribution in the western region of Saudi Arabia. Fifty-one species of snakes can be recognized in Arabia. Nine of these are poisonous sea snakes and the remaining 42 species are terrestrial, of which 9 are poisonous (Mandaviile, 1965; Gasperetti, 1974, 1988; Leviton, $1977 \mathrm{a}, \mathrm{b}$ ) and Al-Sadoon (1989).

Since the beginning of humanity, people have been concerned about their environment and especially its ability to provide them with food, water, and other resources. As our numbers have grown and our technology has developed, we have become increasingly concerned about the impact we are having on our environment (Hunter, 1996).

Modern technology has given humans greatly increased power over nature. This power has done nothing to reduce human dependence on biological diversity, which it simply means the wealth of life forms found on earth: Millions of different plants, animals, and micro-organisms, the genes they contain and the intricate ecosystems they form.

Recently, studies on the biodiversity received a great interest. Reptiles are one of the most important taxa especially in hot countries which are considered as bio indicators to changes in environment and climate (Lambert, 1984). The present work is dealing with ecological and biological studies of herpetofauna of Asir region, Saudi Arabia in detail as one of the natural resources of the area.

\section{MATERIAL AND METHODS}

\section{Study area}

Field trips were carried out to different locations of Asir region, which located in the southwestern part of Saudi Arabia. The geographical area of Asir region is estimated about $81,000 \mathrm{~km}^{2}$. Asir region is located in the center of the South-Western part of the kingdom between Latitudes $17.25^{\circ}$ and $19.50^{\circ}$ in the North and between Longitudes $50.00^{\circ}$ and $41.50^{\circ}$ in the East. Asir region extends from the borders of 
AL-Darb and AL-Shoqiq and Bish (Jazan region) in the Southwest to the borders of Yemen in the Southeast, and from the borders of Wadi Al-Dawasir (Riyadh region) in the North to the Ranyah (Mecca) to (Al Baha area) to Mecca in the coastal plain of Al Qunfudhah. Asir region also extends from the borders of Najran region in the East to Al Qunfudhah province and part of the Red Sea coast and the South Makhwah Province in the West (Fig. 1). The most favorable time for collection is between March and July, when environmental conditions are most suitable for animals to be found.

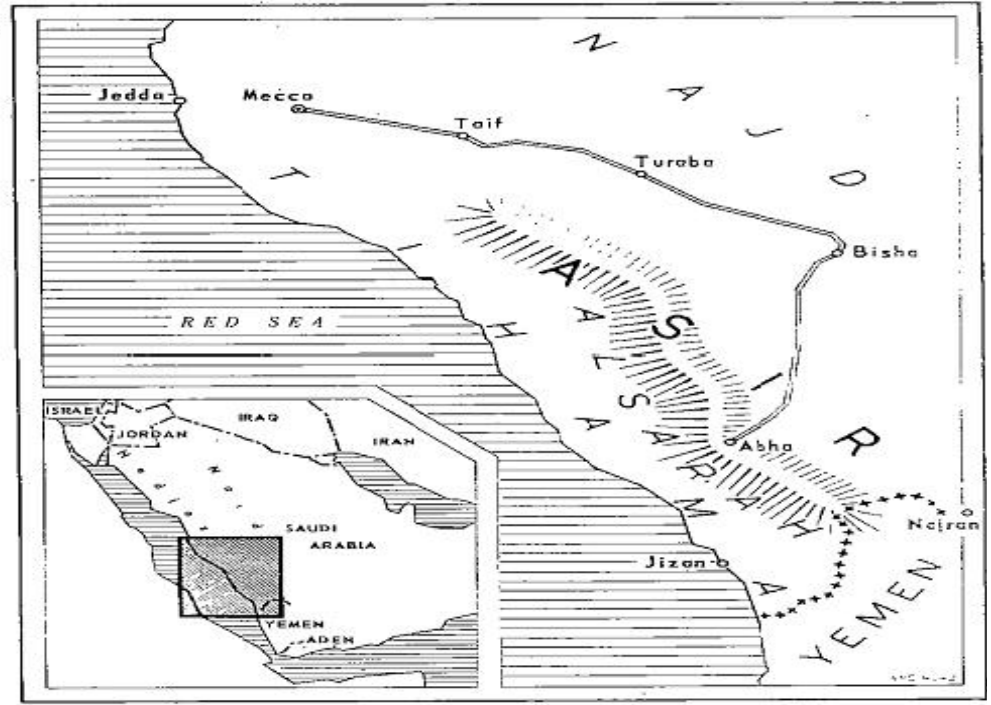

Fig. 1: Map of Saudi Arabia and enlarged part of Asir region is showing the location of the study area.

\section{Geographically}

The Asir region is situated on a high plateau that receives more rainfall than the rest of the country and contains the country's highest peaks, which rise to almost 3,000 meters at Jebel Sawdah near Abha.

\section{Climate of the study area}

Though data is exceedingly sparse and unreliable, the average annual rainfall in the highlands probably ranges from 300 to 500 millimeters (12 to 20 inches) falling in two rainy seasons, the chief one being in March and April with some rain in the summer. Temperatures are very extreme, with diurnal temperature ranges in the highlands the greatest in the world. It is common for afternoon temperatures to be over $30^{\circ} \mathrm{C}\left(85^{\circ} \mathrm{F}\right)$ yet mornings can be extremely frosty and fog can cut visibility to near zero percent. As a result, there is much more natural vegetation in Asir than in any other part of Saudi Arabia, with sheltered areas even containing areas of dense coniferous forests, though more exposed ridges still are very dry. Asir is home to many farmers who chiefly grow wheat and fruit crops, though irrigation has greatly expanded production in modern times.

\section{Sampling methods}

The survey was performed by different methods. Pit-fall trapping is effective method for fossorial species or for land moving lizards or even viprid snakes. Since pit-fall traps could not effectively sample some species, other methods were used. Nocturnal species could be found by following their tracks to their daytime hiding places, such as in holes, under stones or burrows. They could usually be seen by looking for them after dark using an ordinary torch especially for wall geckoes. Diurnal lizards and snakes were collected by catching directly with hands. 
Amphibians were collected in their suitable habitat by hand or hand-net. Some ecological data were collected as microhabitat, date, time of the day and weather. Notes were made on the most salient diagnostic features of each species including color, body measurements, shape, and morphology together with remarks on its behavior, biology and ecology. Date, locality, Co-ordinates: Latitude, longitude and altitude, have been recorded by a GPS (Table 1) time of day and other ecological information were recorded (Table1).

Individuals were identified using standard keys (Leviton et al., 1992; Schleich et al., 1996; Saleh, 1997). Based on the available information, the status of each of herpetofaunal species of the area is estimated according to the IUCN (2004) and IUCN (2005).

Table 1: Co-ordinates: Latitude, longitude and altitude, of the studies area by a GPS

\begin{tabular}{|c|c|c|c|c|}
\hline \multirow{2}{*}{ No } & \multirow{2}{*}{ Location } & \multicolumn{3}{|c|}{ Co-ordinates } \\
\hline & & Altitude (meter) & Latitude & Longitude \\
\hline Site (1) & Amaq & $13 \mathrm{~m}$ & $18^{\circ} 28^{\prime}$ & $41^{\circ} 28^{\prime}$ \\
\hline Site (2) & Hala & $65 \mathrm{~m}$ & $18^{\circ} 46^{\prime}$ & $41^{\circ} 24^{\prime}$ \\
\hline Site (3) & Tholathaa yabh & $60 \mathrm{~m}$ & $18^{\circ} 57^{\prime}$ & $41^{\circ} 21^{\prime}$ \\
\hline Site (4) & Al-Jard & $80 \mathrm{~m}$ & $18^{\circ} 58^{\prime}$ & $41^{\circ} 24^{\prime}$ \\
\hline Site (5) & Al-Qoz & $40 \mathrm{~m}$ & $18^{\circ} 58^{\prime}$ & $41^{\circ} 19^{\prime}$ \\
\hline Site (6) & Sad Al.Makdey Dam Al Soudah & $2637 \mathrm{~m}$ & $18^{\circ} 14^{\prime}$ & $42^{\circ} 25^{\prime}$ \\
\hline Site (7) & AL- Mesealy & $2500 \mathrm{~m}$ & $18^{\circ} 21^{\prime}$ & $42^{\circ} 22^{\prime}$ \\
\hline Site $(8)$ & Dam - Al Sharma & $2450 \mathrm{~m}$ & $18^{\circ} 21^{\prime}$ & $42^{\circ} 22^{\prime}$ \\
\hline Site (9) & Dam- Tamena & $2303 \mathrm{~m}$ & $18^{\circ} 01^{\prime}$ & $43^{\circ} 46^{\prime}$ \\
\hline Site (10) & Wadi Al-Mohala & $2036 \mathrm{~m}$ & $18^{\circ} 19^{\prime}$ & $42^{\circ} 35^{\prime}$ \\
\hline Site (11) & Dam - Abha & $2280 \mathrm{~m}$ & $18^{\circ} 13^{\prime}$ & $42^{\circ} 29^{\prime}$ \\
\hline Site (12) & Wadi Al Makhad & $2520 \mathrm{~m}$ & $18^{\circ} 11^{\prime}$ & $43^{\circ} 26^{\prime}$ \\
\hline Site (13) & $\mathrm{Al}$ Mahmoud & $2450 \mathrm{~m}$ & $18^{\circ} 21^{\prime}$ & $42^{\circ} 22^{\prime}$ \\
\hline Site (14) & Wadi Al- Atf(Forsha) & $1083 \mathrm{~m}$ & $17^{\circ} 47^{\prime}$ & $43^{\circ} 11^{\prime}$ \\
\hline Site (15) & Wadi shenee & $1082 \mathrm{~m}$ & $17^{\circ} 40^{\prime}$ & $43^{\circ} 10^{\prime}$ \\
\hline Site (16) & Wadi treksh & $375 \mathrm{~m}$ & $18^{\circ} 43^{\prime}$ & $41^{\circ} 60^{\prime}$ \\
\hline Site (17) & بقر Wadi Baqra & $115 \mathrm{~m}$ & $18^{\circ} 47^{\prime}$ & $41^{\circ} 59^{\prime}$ \\
\hline Site (18) & Wadi sheree & $365 \mathrm{~m}$ & $18^{\circ} 59^{\prime}$ & $41^{\circ} 54^{\prime}$ \\
\hline Site (19) & Wadi khat & $335 \mathrm{~m}$ & $19^{\circ} 05^{\prime}$ & $41^{\circ} 51^{\prime}$ \\
\hline Site (20) & Wadi Qanona & $175 \mathrm{~m}$ & $19^{\circ} 15^{\prime}$ & $41^{\circ} 28^{\prime}$ \\
\hline Site (21) & Wadi Al-Nazar & $700 \mathrm{~m}$ & $19^{\circ} 27^{\prime}$ & $41^{\circ} 50^{\prime}$ \\
\hline Site (22) & Wadi Om Sahmain & $315 \mathrm{~m}$ & $18^{\circ} 41^{\prime}$ & $41^{\circ} 57^{\prime}$ \\
\hline Site (23) & Wadi Atoad & $1150 \mathrm{~m}$ & $18^{\circ} 03^{\prime}$ & $42^{\circ} 26^{\prime}$ \\
\hline Site (24) & Zahban & $17 \mathrm{~m}$ & $18^{\circ} 06^{\prime}$ & $41^{\circ} 37^{\prime}$ \\
\hline Site (25) & Dam -Ayash & $2050 \mathrm{~m}$ & $19^{\circ} 25^{\prime}$ & $42^{\circ} 03^{\prime}$ \\
\hline Site (26) & Wadi Tarag & $1410 \mathrm{~m}$ & $19^{\circ} 31^{\prime}$ & $42^{\circ} 19^{\prime}$ \\
\hline Site (27) & Wadi Thoryban & $700 \mathrm{~m}$ & $19^{\circ} 27^{\prime}$ & $41^{\circ} 50^{\prime}$ \\
\hline Site (28) & Wadi yabahh & $257 \mathrm{~m}$ & $19^{\circ} 03^{\prime}$ & $41^{\circ} 46^{\prime}$ \\
\hline Site (29) & Alkhanak & $1280 \mathrm{~m}$ & $19^{\circ} 24^{\prime}$ & $42^{\circ} 31^{\prime}$ \\
\hline Site (30) & Rabood mountain & $1320 \mathrm{~m}$ & $19^{\circ} 18^{\prime}$ & $43^{\circ} 29^{\prime}$ \\
\hline Site (31) & Al-Mostawa & $1285 \mathrm{~m}$ & $19^{\circ} 21^{\prime}$ & $43^{\circ} 32^{\prime}$ \\
\hline Site (32) & Wadi Al Nazar & $712 \mathrm{~m}$ & $19^{\circ} 28^{\prime}$ & $41^{\circ} 51^{\prime}$ \\
\hline Site (33) & $\mathrm{Al}$ Joba & $2365 \mathrm{~m}$ & $18^{\circ} 01^{\prime}$ & $43^{\circ} 10^{\prime}$ \\
\hline Site (34) & Dam - Bisha & $1280 \mathrm{~m}$ & $19^{\circ} 39^{\prime}$ & $43^{\circ} 33^{\prime}$ \\
\hline Site (35) & Bisha & $1100 \mathrm{~m}$ & $20^{\circ} 10^{\prime}$ & $43^{\circ} 40^{\prime}$ \\
\hline Site (36) & Al_Qaobaa & $1370 \mathrm{~m}$ & $19^{\circ} 33^{\prime}$ & $42^{\circ} 17^{\prime}$ \\
\hline Site (37) & Dam Ashran & $4302 \mathrm{~m}$ & $18^{\circ} 16^{\prime}$ & $42^{\circ} 27^{\prime}$ \\
\hline Site (38) & Al-Dahnaa & $2290 \mathrm{~m}$ & $18^{\circ} 55^{\prime}$ & $42^{\circ} 12^{\prime}$ \\
\hline Site (39) & Al-Shaaf & $2145 \mathrm{~m}$ & $19^{\circ} 00^{\prime}$ & $41^{\circ} 00^{\prime}$ \\
\hline Site (40) & Al-Bhim & $1330 \mathrm{~m}$ & $19^{\circ} 43^{\prime}$ & $42^{\circ} 22^{\prime}$ \\
\hline Site (41) & Dam - Nabaa (Al-bshair) & $1330 \mathrm{~m}$ & $19^{\circ} 43^{\prime}$ & $42^{\circ} 22^{\prime}$ \\
\hline Site (42) & Abha & $2270 \mathrm{~m}$ & $18^{\circ} 13^{\prime}$ & $42^{\circ} 31^{\prime}$ \\
\hline Site (43) & Al Alaya & $2200 \mathrm{~m}$ & $19^{\circ} 37^{\prime}$ & $41^{\circ} 54^{\prime}$ \\
\hline
\end{tabular}




\section{RESULTS}

\section{Species composition}

\section{1- Class Amphibia}

The results showed that there are seven anuran species, belong to the three families, Bufonidae, Ranidae and Hylidae (Four species of family Bufonidae: Bufo tihamicus, B. dhufarensis, B. arabicus and B. viridis; one species of family Hylidae: Hyla savignyi; and two species of family Ranidae Rana ridibunda and Euphlyctis ehrenbergii ).

Systematic list of the recorded species

\section{Order Anura}

Family Bufonidae

Genus Bufo Laurenti, 1768

Bufo viridis viridis Laurenti, 1768

Common name: Green Toad.

Arabic name: dufda'a khadru' green toad.

Distribution: Europe, North Africa, eastward to Mongolia and Tibet.

Distribution in Asir: Sites (6, 7, 8)

Habitat and ecology: Semi-desert with some scattered mesic microhabitats, oases, cultivations on the desert margins. Found in wells, cisterns, and brackish marshes. Capable of tolerating very dry conditions and it is the only amphibian in much of the Asir deserts. However, it is only able to survive at localities where permanent or at least seasonal water sources (such as wells and rain pools) are readily available. At such localities, the species is often found very abundantly especially during the breeding season, when hundreds of animals might congregate at a single water source.

Ecology: Nocturnal except during the mating period.

Status and conservation needs: Fairly common and widespread. Classified as Least Concern by IUCN (2004).

Bufo arabicus Heyden, 1827

Common name: The Arabian Toad.

Arabic name: The Arabian Toad.

Distribution: Europe, North Africa, eastward to Mongolia and Tibet.

Distribution in Asir: Sites (8,14,15,16,17,18,19, 20,21,26,27,28, 33,34,35,36,37,38,39,42)

Habitat and ecology: An opportunistic, mesophilous species, is found in almost all environments of the peninsula where water is available (Balletto, et al., 1985). It lives in wadis, gravel areas, gardens and date groves, and is active both by day and night. The breeding season of this species follows the rain. Two breeding seasons have been recorded in Yemen and Saudi Arabia, one in September-October and the other in June-July (Balletto, et al. 1985).

Status and conservation needs: Fairly common and widespread. Classified as Least Concern by IUCN (2005).

Bufo dhufarensis Parker, 1931

Common name: Dhofar toad.

Arabic name: Dhofar toad.

Range: Bufo dhufarensis is limited to peripheral Arabia, ranging from western Saudi Arabia (Mecca) south to Yemen thence east to northern Oman.

Distribution in Asir: Sites (1, 19, 22, 27) 
Habitat and ecology: Its natural habitats are subtropical or tropical dry shrub land, rivers, intermittent rivers, freshwater springs, rural gardens, urban areas, ponds, and irrigated land.

Ecology: Nocturnal except during the mating period.

Status and conservation needs: Fairly common and widespread. Classified as Least Concern by IUCN (2005).

Bufo tihamicus Balletto and Cherchi, 1973

Common name: Balletto's Toad.

Arabic name: Tohama toad.

Distribution: Saudi Arabia, Yemen.

Distribution in Asir: Sites (1, 2, 3, 4, 5)

Habitat and ecology: It can be found in arid vegetation (except in riparian vegetation close to wadis) and wherever there are available water sources. It breeds in still or slow moving water. It is common in arable land close to wadis.

Status and conservation needs: Fairly common and widespread. Classified as Least Concern by IUCN (2004).

Family Hylidae

Hyla savignyi Audouin, 1829

Arabic name: Dufda'at Al-shajar

Distribution: Southwest Asia, the Levant, south into western Arabia to Yemen.

Distribution in Asir: Sites (6, 7,8, 9, 10, 12, 25, 39, 41,42, 43 )

Habitat and ecology: Vegetation in and near wetlands; also in orchards, gardens, and cultivations in close proximity to wetlands. Sometimes found quite a long distance from water. Nocturnal, with some diurnal activity. Spends much of its time well camouflaged, in arboreal situations, high above ground.

Status and conservation needs: Classified as Least Concern by IUCN (2004).

Family Ranidae

Genus Rana Linnaeus, 1758

Rana ridibunda Pallas, 1771

Common name: Lake Frog.

Distribution: North Africa, central and southern Europe into west Asia.

Distribution in Asir: Sites (6, 8, 9, 10, 11, 12, 13)

Habitat: Fresh water ponds and canals. It was found in brackish marshes with dense emergent vegetation.

Ecology: Crepuscular. It feeds on insects and small invertebrates.

Status: Lower Risk (least concern).

Euphlyctis ehrenbergii (Peters, 1862)

Common name: dufda'at al-Rasheek.

Distribution: This species is restricted to areas of permanent and temporary water in the Red sea coastal region of Yemen and Saudi Arabia. It has an altitudinal range of sea level to $2,400 \mathrm{~m}$.

Distribution in Asir: Sites (5, 13,14,15,16,17,18,19,20,21,22,23, 24, 25, 26)

Habitat: It is a highly aquatic species, found in temporary and permanent water bodies. It is also present in irrigated areas. Eggs are laid in the water. The species may aestivate during the dry season.

Ecology: Crepuscular. It feeds on insects and small invertebrates.

Status: Lower Risk (least concern).

2- Class Reptilia

There are 38 species of reptiles (23 species of lizards belonging to the families: Gekkonidae, Lacertidae, Scincidae, Agamidae, Varanidae, and Chamaeleontidae and 
14 species of snakes belonging to 5 families: Typholopidae, Leptotypholopidae, Colubridae, Elapidae, and only one species of Turtles belongs to family Testudinidae) were identified and recorded.

Order Squamata

Suborder Sauria

Family Gekkonidae

Genus Hemidactylus Oken, 1817

Hemidactylus turcicus (Linnaeus, 1758)

Common name: Turkish Gecko, Warty Gecko, Mediterranean Gecko.

Distribution: North Africa.

Habitat: It is mostly found on rocks and it also frequents walls of old buildings. It was found in the study area hidden under stones in destroyed building in salt marsh habitat.

Distribution in Asir: Sites (1,2,3,4,5,6, 7,8,14,15,16,17,18,19, 20,21,26,27,28, 33, 34, 35, 36, 37, 38, 39, 42)

Ecology: It occurs mostly in contact with human settlement. It is a most house gecko (Saber, 1999).

Status: Very common. It is classified as Least Concern by IUCN (2005).

Hemidactylus flaviviridis Ruppell, 1840

Common name: Yellow-bellied House Gecko.

Distribution: Northeast African and Arabian shores of the Red Sea and around the coasts of Arabia and Iran, across Pakistan, eastern Afghanistan and northern India.

Distribution in Asir: Sites (1,2,3,4,5,6,10,15,16,17, 18, 19, 24, 35, 36, 37, 38, 39, 42)

Habitat: It is mostly found on rocks and it also frequents walls of old buildings. It was found in the study area hidden under stones in destroyed building in salt marsh habitat.

Ecology: It occurs mostly in contact with human settlement. It is a most house gecko.

Status: Very common. It is classified as Least Concern by IUCN (2005).

Genus Tarentola Gray, 1825

Tarentola annularis annularis (Geoffory, 1827)

Common name: Egyptian Gecko, white-spotted gecko.

Arabic name: Bors Abu Arba Noqat.

Distribution: Egypt, Libya, Sudan, Ethiopia, Northern Somalia, Chad, Niger, Mali, Gambia, Senegal, Guinea, Bissau, Mauritania, Western Sahara \& southern Morocco (Marx, 1968).

Distribution in Asir: Sites (5,6, 7, 8,14,15,16,17,18,19, 26, 28, 33, 34, 35, 36, 37, 38, 39,40, 42)

Habitat: It is found on rocks and ruins, but it also frequents houses.

Ecological remarks: A crepuscular species, feeds on insects, sit-and wait forager, and territorial.

Zoogeographical distribution: Ethiopian, relict in the Saharan Province.

Status: Classified by IUCN (2005) as Lower Risk, Least Concern (LC).

Tarentola mauritanica mauritanica Linneaus, 1758

Common name: Moorish Gecko.

Distribution: Egypt westwards to Morocco and Western Sahara, and Canary and Madeira Islands.

Distribution in Asir: Sites (4, 7, 8, 10,16,22, 34, 35, 36, 37, 38, 39, 42, 43)

Habitat: Rock cliffs, stone heaps, stone walls, buildings and tree trunks.

Ecology: Mainly nocturnal but can also be seen active during daytime. It feeds on insects and small vertebrates. Schleich et al. (1996) mentioned that a gecko of this species was found feeding on a solpugid of size much bigger than its own head.

Status: Thousands of individuals are exported every year. It is classified as Least Concern by IUCN (2005). 
Genus Tropiocolotes Peters, 1880

Tropiocolotes tripolitanus (Peters, 1880)

Common name: Tripoli Gecko.

Distribution: Egypt westwards to Tunisia.

Distribution in Asir: Sites (9, 12,14,15,16, 26, 28, 29, 30, 31, 35, 42, 43)

Habitat: Rock, gravel and sand desert.

Ecology: A nocturnal species feeding on small insects. It is usually found under stones or other objects in the desert.

Status: It is classified as Least Concern by IUCN (2005).

Genus Gymnodactylus (Ground geckos)

Gymnodactylus scaber Heyden, 1827

Common name: Rough-scaled Gecko, Keeled Rock Gecko.

Arabic name: Bors Rafieh El Asabih.

Distribution: Turkey, Egypt, Iraq, Iran, Saudi Arabia, Oman, United Arab Emirates, Ethiopia, Eritrea, Sudan, India, Pakistan, Jordan, Afghanistan, USA.

Distribution in Asir: Sites (2,3, 5,7,10, 13, 17, 20, 23, 24,32, 33, 35,39, 40, 42)

Habitat: It is mostly found on rocks and it also frequents walls of old buildings. It was found in the study area hidden under stones in destroyed building in salt marsh habitat.

Ecology: In Egypt, it has been collected in rocky areas and old buildings. In the Arabian Peninsula, it is considered a common house gecko. This gecko appears to be diurnal. It moves very swiftly on rocks, jumping from one rock to another.

Status: Very common. It is classified as Least Concern by IUCN (2005).

Genus Stenodactylus Fitzinger, 1826

Stenodactylus sthenodactylus (Lichtenstein, 1823)

Common name: Elegant Gecko.

Arabic name: Burs Abu Ain Wasaa.

Distribution: Northern Africa southwards to Senegal, Nigeria, Mali, Ethiopia, Eritrea, Sudan and eastwards to Jordan and Palestine.

Distribution in Asir: Sites (1, 5, 9, 12, 15, 19, 22, 23, 29, 30, 32, 33, 35, 40, 42)

Habitat: Gravelly and coarse sandy plains and large wadis and rarely in dune areas. They distribute altitudinally from 40 to $1500 \mathrm{~m}$ above sea level.

Ecological remarks: Nocturnal and ground dwelling gecko, widespread but generally in small numbers.

Zoogeographical distribution: Palaearctic (Saharo-Sindian).

Status: Classified by IUCN (2005) as Lower Risk, Least Concern (LC).

Genus Ptyodactylus Goldfuss, 1820

Ptyodactylus hasselquistii hasselquistii (Donndorff, 1798)

Common name: Fan-footed Gecko.

Arabic name: Al-bors Abo-kaf.

Distribution: Egypt, southern, extreme southern Morocco to Western Sahara and Mauritania (Marx, 1968).

Distribution in Asir: Sites (1,2,4,6,11,13,18,21,22, 24,25, 29, 30, 32, 35,38, 40, 42,43)

Habitat: It is a rock dwelling gecko mainly in stone cliffs in desert and on building.

Ecological remarks: It is active both by day and night. It feeds mainly on insects.

Foraging strategy is sit and wait. It performs color change (Saber et al, 1994).

Zoogeographical distribution: Palaearctic (Mediterranean).

Status: Classified by IUCN (2005) as Lower Risk, Least Concern (LC).

Family Agamidae

Genus Pseudotrapelus Fitzinger, 1843

Pseudotrapelus sinaitus (Heyden, 1827) 
Common name: Sinai Agama.

Arabic name: Qady Sina, Qady Al-Gabal.

Distribution: Palestine, Jordan, Arabia, Egypt, Eritrea, and southeast Libya.

Distribution in Asir: Sites (3,7,9,10,12,14,16,17,19,21,23,26,27,28,30, 35,42)

Habitat: It inhabits very dry rocky areas in mountainous and hilly regions.

Ecological remarks: A diurnal species, insectivorous, sit-and-wait forager, territorial. The color of this species relates to its psychological condition. When excited, the lizard assumes the bright color pattern, with blue head and reddish brown spots on the dorsum. A resting animal has a much duller color (Saleh, 1997).

Zoogeographical distribution: Palaearctic (Saharo-Sindian).

Status: Classified by IUCN (2005) as Lower Risk, Least Concern (LC).

Genus Trapelus Cuvier, 1816

Trapelus pallidus pallidus (Reuss, 1834)

Common name: Pale Agama.

Arabic name: Qady Al-Gabal.

Distribution: Iraq, Kuwait and northern Saudi Arabia.

Distribution in Asir: Sites (2,3,5,7,9,12,13,16,17,18,22,23,26,27,28,30,32,35, 43)

Habitat: Open sandy and gravel desert with low precipitation.

Ecological remarks: A diurnal ground dwelling species, main activity in the morning and afternoon hours. With proceeding autumn the activity is reduced to the hours around noon. It hibernates in winter. It avoids overheating in plants' shadow or by climbing on branches or rocks. Insectivorous, sit-and wait forager and may run after prey. Territorial, especially during reproductive period. (Schleich et al., 1996).

Zoogeographical distribution: Palaearctic (Saharan).

Status: Classified by IUCN (2005) as Lower Risk, Least Concern (LC).

Trapelus mutabillis Merrem, 1820

Common name: Changeable Agama.

Distribution: North Africa from Tunisia to Egypt west of the Nile.

Distribution in Asir: Sites $(1,2,4,5,10,12,13,14,15,17,18,20,21,22,23,26,27,28,30,32,35,39,40)$

Habitat: Vegetated sand or gravel desert.

Ecology: A diurnal species, very tolerant to heat and hunger, avoid overheating in plants shadow or by climbing on branches or rocks, feeds on a wide spectrum of insect species.

Status: Widespread and common, threatened by intensive commercial collection. It is classified as Least Concern by IUCN (2005).

Genus Laudakia Gray, 1845

Laudakia stellio stellio (Linnaeus, 1758)

Common name: Starred Agama.

Distribution: Southeast Europe, Turkey to Syria, Lebanon, Palestine, Northern Iraq, Northern Sinai and Lower Egypt.

Distribution in Asir: Sites (1, 3, 4,5,7,9,12,13,16,17,19,22,23,27,28,30,32,36,37,40, 42)

Habitat: Rocky surfaces and walls of old buildings.

Ecology: Strictly nocturnal, insectivorous. It is often arboreal when large trees are available. It refuges into crevices or climb up high on walls or trees.

Status: The main threat to this species is commercial over exploitation. In the study area, this species is near threatened; the main reason is the destruction of suitable habitat by quarrying. It is classified as Least Concern by IUCN (2005).

Genus Uromastyx (Merrem, 1820)

Uromastyx aegyptia microlepis Blanford 1874

Common name: Dhub, spiny- tailed lizard. 
Distribution: Southeast Europe, Turkey to Syria, Lebanon, Palestine, Northern Iraq, Northern Sinai and Lower Egypt.

Distribution in Asir: Sites (1, 3, 4,5,7,9,12,13,16,17,19,22,23,25,27,28,30,32,36,37,40, 42, 43)

Habitat: A diurnal ground dwelling species, which inhabits gravel plain and fairly wide wadis with coarse substrate and scattered vegetation.

Ecology: Mainly herbivorous, which forages on a wide variety of plant species.

Status: The main threat to this species is commercial over exploitation. In the study area, this species is near threatened; the main reason is the destruction of suitable habitat by quarrying. It is classified as Least Concern by IUCN (2005).

Family Amphisbaenidae

Genus Diplometopon Nikolsky, 1907

Diplometopon zarudnyi Nikolsky, 1907

Common name: Zarudnyi's Worm Lizard, sehlhia dedania.

Distribution: The range of this species extends to northern Arabia and the coastal Arabian Gulf.

Distribution in Asir: Sites (1,2,3,5,7,9,10,11,12,13,14,17,18,20,23,25,27,30,31,35,38,40, 42)

Habitat: commonly found burrowing in low sand dunes in open terrain and in subsurface soils of date palm farms.

Ecology: It is a nocturnal forager, sometimes occupying ant and termite tunnels.

Status: Very common. It is classified as Least Concern by IUCN (2005).

Family Lacertidae

Genus Acanthodactylus Fitzinger, 1834

Acanthodactylus boskianus asper (Daudin, 1829)

Common name: Bosc's Lizard.

Distribution: Widespread throughout North Africa and Southwestern Asia.

Distribution in Asir: Sites $(3,4,5,9,10,12,13,14,15,18,21,22,24,26,27,28,29,30,31,35,38,40,42)$

Habitat: Sparsely vegetated areas with gravel and stones but less often sand.

Ecology: A diurnal species feeds on a variety of food items. A diurnal species may be active in the morning and afternoon in summer and around noon in fall and winter.

Zoogeographical distribution: Palaearctic (Saharo-Sindian).

Status: Classified by IUCN (2005) as Lower Risk Least Concern (LC).

Acanthodactylus scutellatus scutellatus (Audouin, 1829)

Common name: Nidua Lizard.

Distribution: North Africa to South-western Asia.

Distribution in Asir: Sites $(1,3,4,5,9,10,12,13,14,15,18,21,22,24,27,29,30,31,35,38,40,42,43)$

Habitat: Open sandy desert.

Ecology: A diurnal species feeds on small insects.

Status: Very common. It is classified as Least Concern by IUCN (2005).

Genus Mesalina Gray, 1838

Mesalina guttulata (Lichtenstein, 1823)

Common name: Small-spotted Lizard. Sihliya saghirat al nuqat.

Distribution: The Saharo-Sindian region from Morocco to Iran, south to the Sahel.

Distribution in Asir: Sites $(2,3,5,6,9,10,12,13,15,16,17,20,22,24,26,27,28,29,30,31,35,38,40,42)$

Habitat: It was on stony plateau of sandy or rocky areas with light vegetation.

Ecology: A diurnal, insectivorous, escapes to hide between vegetation.

Status: The main threat to this species in the study area is the limited distribution and habitat destruction. This species is near threatened. It is classified as Least Concern by IUCN (2005).

Family Scincidae

Genus Chalcides Laurenti, 1763

Chalcides ocllatus ocellatus (Forskal, 1775) 
Common name: Eyed Skink, Ocellated Skink.

Distribution: North Africa to South-Eastern Europe and South-western Asia. Distribution in Asir: Sites(9,10,12,14,15,16,19,20,21,22,23, 26,27,28,29,30,32,33, 35,37,38,40, 42)

Habitat: Sandy desert. It may inhabit also banks of irrigation canals.

Ecology: It is crepuscular, semifossorial, living under sand or dead vegetation. It can sand-swim with great speed to avoid danger. It prefers a mosaic of open ground for basking and dense vegetation for hiding.

Status: Common and widespread. It is classified as Least Concern by IUCN (2005).

Genus Trachylepis Fitzinger, 1843

Trachylepis vittata (Olivier, 1804)

Common name: Bridled Skink.

Distribution: North Africa and south-west Asia.

Distribution in Asir: Sites(1,2,3,5,8,13,16,19,20,22,23,24, 26,31,33, 35,36,37)

Habitat: Sandy desert with dense vegetation.

Ecology: A diurnal, but spends the hottest hours of the day in its burrow. It digs burrows between the roots of the vegetation.

Status: It is classified as Least Concern by IUCN (2005).

Genus Scincus Laurenti, 1768

Scincus scincus scincus (Linnaeus, 1758)

Common name: Sandfish.

Distribution: North-eastern Africa.

Distribution in Asir: $\operatorname{Sites}(9,10,12,14,15,16,17,18,20,21,22,23,27,28,32,33,35,43)$

Habitat: Sandy desert, preferable where accumulations of loose drifting sand with rich vegetation, often around roots.

Ecology: Fossorial, sand swimming species.

Status: Common and widespread. It is classified as Least Concern by IUCN (2005).

Genus Eumeces Wiegmann, 1834

Eumeces schneiderii (Daudin, 1802)

Common name: Gold Skink, Orange-tailed Skink.

Distribution: North Africa and west Asia.

Distribution in Asir: Sites(6,8,9,10,11,16,19, 25,26,27,28,30,32,33, 35,38,39)

Habitat: Sandy desert with dense vegetation.

Ecology: A diurnal, but spends the hottest hours of the day in its burrow. It digs burrows between the roots of the vegetation.

Status: Vulnerable, the main threat to this species is commercial over exploitation. It is classified as Least Concern by IUCN (2005).

Family Varanidae

Genus Varanus Merrem, 1820

Varanus griseus griseus (Daudin, 1803).

Common name: Desert Monitor, Gray Monitor.

Distribution: North Africa and South-west Asia.

Distribution in Asir: Sites $(1,4,7,10,12,14,15,16,19,20,21,22,24,29,35,40)$

Habitat: Sandy desert.

Ecology: A diurnal carnivorous species feeds mainly on lizards and rodents. It has a large home range.

Zoogeographical distribution: Palaearctic (Saharo-Sindian).

Status: Fairly common and widespread. Large numbers are collected for the pet trade in the international market. Classified by IUCN (2005) as Lower Risk, Least Concern (LC).

Family Chamaeleontidae 
Genus Chamaeleo Laurenti, 1768

Chamaeleo chamaeleon chamaeleon Linnaeus, 1758

Common name: Common Chameleon, European Chameleon.

Distribution: South Europe, North Africa, and South-west Asia.

Distribution in Asir: Sites (1,2,6,8,11,13,17,18,19,20,23,25,28,31,34,35,41)

Habitat: Vegetated desert area with bushes or trees.

Ecology: Arboreal, found on trees and bushes. When food becomes scarce they move away, even on the ground.

Status: It is vulnerable. It is classified as Least Concern by IUCN (2005).

Suborder Ophidia (Serpents)

Family Typhlopidae

Genus Ramphotyphlpos Fitzinger, 1843

Ramphotyphlops braminus (Daudin, 1803)

Common name: Bah dudi aswad, Brahminy blind snake.

Distribution: Africa and Asia, but being an introduced species in many parts of the world, it is also found in Australia and the Americas. It is common throughout most of Florida.

Distribution in Asir: Sites (1, 2, 6, 7, 8,9,11,12,16,17,24,25,34, 35,41)

Habitats and ecology: Usually occurs in urban and agricultural areas. These snakes live underground in ant and termite nests. They are also found under logs, moist leaves and humus in wet forest, dry jungle and even city gardens. The distribution and survival of this group of snakes directly reflects soil humidity and temperature.

Biology: Their diet consists of the larvae, eggs, and pupae of ants and termites.

Status: Probably widespread and fairly common species. It is classified as Least Concern by IUCN (2005).

Genus Leptotyphlops Fitzinger, 1843

Leptotyphlops macrorhynchus (Jan, 1861)

Common name: Hook-billed Blind Snake, Beaked Thread Snake, Bah Sahrawi.

Distribution: Widely distributed from northeast Africa and Arabia to Pakistan, Turkey to the northwestern India (Leviton et al., 1992).

Distribution in Asir: Sites (1,2,5,6,8,11,13,17,22,24,25,29,31,34,35,37,38,41)

Habitats and ecology: This snake was collected from a dry region with low annual rainfall, although, it was taken from under a rock with damp soil. Another specimen was collected from the sand-stone desert. Corkill (1932) reported that the Hook-billed Blind Snake is a nocturnal species. Habitats include river banks, coastal plain sands, and houses (Schleich et al., 1996).

Biology: Several authors reported the insectivorous diet for this species (Corkill, 1932; Schleich et al., 1996). Platyceps rhodorhachis was found to feed on this blind snake (Mulder, 2002).

Status: Probably widespread and fairly common species. It is classified as Least Concern by IUCN (2005).

Family Colubridae

Genus Platyceps Blyth, 1860

Platyceps elegantissimus (Günther, 1878)

Common name: Most Beautiful Whip Snake.

Distribution: Northwestern, central Arabia, Palestine and Jordan, Israel.

Distribution in Asir: Sites (1,3,4,7,9,12,13,16,19,20,26,31,35,39,40,42,43)

Habitats and ecology: One specimen was found submerged in water. This species was collected from hard sandstone and rocky habitats The Most Beautiful Whip Snake is a nocturnal species. It feeds mainly on lizards. 
Status: Rather uncommon but widespread species. It is classified as Least Concern by IUCN (2005).

Platyceps rhodorhachis (Jan, 1865)

Common name: Azrud jabali rafi.

Distribution: Libya to northwestern India and Syria to the Arabian Peninsula.

Distribution in Asir: Sites (1,2,4,7,9,12,13,17,19,20,26,31,35,38,39,40,42,43)

Habitat: Inhabits rocky areas in arid mountains region, wadis, ruins, often near oases and cultivation.

Ecology: Diurnal change to nocturnal activity during the hottest months. It feeds mainly on lizards.

Status: Rather uncommon but widespread species. It is classified as Least Concern by IUCN (2005).

Platyceps rogersi (Anderson, 1893)

Common name: Spotted racer.

Distribution: Libya, Egypt, Palestine, Jordan, western Iraq and northern Saudi Arabia.

Distribution in Asir: Sites (2,3,5,7,9,12,13,17,19,20,26,28,32,35,38,39,40,42)

Habitat: Stony or sandy desert.

Ecology: Diurnal change to nocturnal activity during the hottest months. One specimen was found active at the study area at 9 o'clock at night on August $15^{\text {th }}$ in sandy vegetated habitat. It feeds mainly on lizards.

Status: Fairly common. It is classified as Least Concern by IUCN (2005).

Genus Lytorhynchus Peters, 1863

Lytorhynchus diadema (Dumeril, Bibron and Dumeril, 1854)

Common name: Diademed Sand-snake.

Distribution: North Africa and South-west Asia.

Distribution in Asir: Sites (9,10,12,14,15,18,21,22,23,27,29,30,35,42)

Habitat: Loose sandy areas.

Ecology: It is essentially nocturnal, but may become crepuscular in colder weather. It is assumed that it digs for lizards hidden in the sand.

Status: Lower Risk (least concern).

Genus Malpolon Fitzinger, 1826

Malpolon moilensis (Reuss, 1834)

Common name: Moila Snake.

Distribution: North Africa and south-west Asia.

Distribution in Asir: Sites (3,9,10,12,13,14,16,19,20,32,35,40)

Habitat: Vegetated sandy desert.

Ecology: A diurnal snake, but becomes crepuscular in hotter weather. It feeds on lizards, snakes, small birds and rodents. An effect of bite on human is more serious than other colubrid snakes.

Status: It is classified as Least Concern by IUCN (2005).

Genus Spalerosophis Jan, 1865

Spalerosophis diadema cliffordi (Schlegel, 1837)

Common name: Clifford' Snake; Clifford's Royal Snake.

Distribution: North Africa south to Sudan east to Sinai, Palestine, Jordan, Syria, Iraq, Arabia and western Iran.

Distribution in Asir: Sites (1,3,9,10,12,14,16,18,19,20,32,35,40,42,43)

Habitat: Sandy and stony desert.

Ecology: Nocturnal or crepuscular. It feeds on lizards and small rodents and birds.

Status: It is classified as Least Concern by IUCN (2005).

Genus Psammophis Fitzinger, 1826 
Psammophis schokari schokari (Forsskal, 1775)

Common name: Schokari Sand Snake.

Distribution: North Africa, eastward through Iran, into arid west Pakistan and India.

Distribution in Asir: Sites (1,2,10,11,13,14,17,18,21,26,29,30,31,32,35,36,39,42)

Habitat: Sandy desert with vegetation.

Ecology: Diurnal animals, very quick moving; often climb in bushes. Feeding mainly on lizards especially Acanthodactylus.

Status: It is classified as Least Concern by IUCN (2005).

Family Elapidae

Genus Naja Laurenti, 1978

Naja haje arabica (Linnaeus, 1758)

Common name: Arabian Cobra.

Arabic name: Al-Cobra, Al-Nashir.

Distribution: Africa and Arabia.

Distribution in Asir: Sites (5,10,12,15,16,20,22,23,27,30,31,32,35,37,38,42,43)

Habitat: It inhabits areas with at least some vegetation and water, never in deserts, steppes, dry savannahs, semi desert, margin of deserts, in oases, wadis, on farmland near old wall or ruins, in ditches along roads and on hills with sparse vegetation.

Behavior: It occasionally enters human habitations, frequently near water. In Egypt, it was met on margins of the backwaters left by the retiring Nile (Anderson, 1898). Herbert (1981) saw this species swimming in the Mediterranean Sea. An aggressive snakes attacking viscously when cornered, its characteristic cobra threat stance with the elevated anterior part of the body and dilated hood is very characteristic (Saleh, 1997). Very quick by lateral undulation swims voluntarily across broad watercourses and it were occasionally observed climbing on trees. Schleich et al. (1996) reported that mating is in early summer. It hides in loose soil, abandoned rodent burrows, old termite mounds or under rocks. Oviparous: oviposits in July-August, incubation period 48-52 days.

Activity Pattern: Diurnal, but Schliech et al. (1996) said that this species is mostly crepuscular and nocturnal, but it can often be seen active by day even during the hottest hours.

Feeding: It feeds on frogs, toads, fish, birds and small mammals.

Mode of feeding: Active searcher.

Zoogeographical Distribution: Saharan and Ethiopian species.

Status: Widespread and common, threatened by intensive commercial collection. This species is near threatened. It is classified as Least Concern by IUCN (2005).

Family Viperidae

Genus Cerastes Laurenti, 1768

Cerastes cerastes gasperetti (Leviton \& Anderson, 1967)

Common Name: Greater cerastes Viper, Horned Viper.

Arabic Name: Haiya Al-Moqrana, Hayya umm jnaeb, or horned snake.

Distribution: This species is widely distributed throughout Africa to southwestern Asia. Marx (1968). In Saudi Arabia, it has been reported from Alula, Duba, Ummlij, Dirs (Farag and Banaja, 1980) and from Bishah, Jabrin, Abqaiq, Dharan, Al-Jubayl, Badanah and Mahd Al-Dhahab (Gasperetti, 1974, 1988). It is the commonest snake in the Central Region (Al-Sadoon, 1989).

Distribution in Asir: Sites (4,5,7,9,13,15,16,20,22,23,27,30,31,32,35,37,38,40)

Habitat: Horned vipers are true desert snake, preferring sandy soil with some vegetation rocky outcrops as shelters.

Activity Pattern: Nocturnal activity. 
Feeding: It ranges long distances in search prey, which is mainly small birds (songbirds) or small mammals (Gerbillus, Mus and Rattus), Lizards and occasionally young or small snakes.

Mode of feeding: Depending upon the availability of food, it has two ways in feeding strategies (Sit \& wait and active searcher feeding).

Zoogeographical Distribution: Palaearctic species.

Behavior: It is a true side winder, never have been seen to employ any other type of locomotion. Preferred hiding places are burrows of small rodents and Uromastyx, also under grass tussocks, small shrubs or flat rocks. They were even found in concrete water conducts. Mating in April-June depending on the climate. Oviposition in JulyAugust, incubation period 6-8 weeks, hatching mostly in October. Saleh (1997) reported that some individuals have two horns located above the eyes and are made of single spine each. Hornless individual are also common. Horned and hornless individuals are found in males and females of all age groups from the same locality or even the same brood. The percentage of horned to hornless individuals in a population differs from one area to another.

Status: Widespread and common, threatened by intensive commercial collection. This species is near threatened in Saudi Arabia; it is classified as Least Concern by IUCN (2005).

Genus Echis Merrem, 1920

Echis coloratus Gunther, 1878

Common Name: Burton's Carpet Viper.

Arabic Name: Haiya Ghariba, Al-ragtag or spotted snake.

Distribution: Sinai, Israel and Arabian Peninsula.

Distribution in Asir: Sites (7,9,10,12,14,15,16,17,20,21,23,26,29,30,31,32,35,37,38,40)

Habitat: Strictly associated with vegetated rocky Wadis.

Feeding: It feeds on small frogs, toads, small reptiles and small rodent, but Schliech et al. (1996) found in its stomach a scorpion, a spider, termites and small beetles.

Mode of feeding: Chiefly nocturnal, but it is also found basking in the early morning (in spring and autumn).

Behavior: This species observed wandering at night in search of rodents that form their main food. In daytime, they conceal themselves below sand or below vegetation. They also make use of burrows of rodents. Occasionally, they climb in bushes up to a height of two meters. A very dangerous snake, venom is strongly coagulant and contains neurotoxin element. Oviparous, mating in August and September. Incubation 50-64 day at temperature $32^{\circ} \mathrm{C}$ (night).

Zoogeographical Distribution: Saharan.

Status: Fairly common and widespread. Classified as Least Concern by IUCN (2005).

Echis carinatus (Schneider, 1801)

Common Name: Saw-scaled viper.

Arabic Name: Haiya Ghariba Samra.

Distribution: Throughout Africa north of the Equator, throughout southern Asia to India and Ceylon.

Distribution in Asir: Sites (7,9,10,12,14,15,16,20,21,22,27, 30,32,33,36,37,38,42,43)

Habitat: Desert, semi deserts and sandy plains, sometimes in grassy terrain on cultivated land and gardens at the border of oases.

Activity Pattern: Mainly Nocturnal.

Feeding: It feeds on lizards, rodents, small birds, scorpions, small beetles, small frogs, toads, Small Mice, and rates. 
Mode of feeding: Depending upon the availability of food, it has two ways in feeding strategies (Sit \& wait and active search feeding).

Behavior: It buries itself in the sand tail first with shoveling motions of the flattened body without changing the location of the body loops. Only the eyes and nostrils remain above the surface. The hidden snakes can be discovered by following their traces. Oviparous, mating in August and September, incubation, 50 - 64 days. Saleh (1997) reported that this is probably the most dangerous snake in Jazan. Its venom is extremely potent.

Zoogeographical Distribution: Saharan.

Status: Uncommon, and much localized because it is often found in high densities it is susceptible to intensive collecting by commercial animal collectors. This species is near threatened in Saudi Arabia. It is classified as Least Concern by IUCN (2005).

Bitis arietans arietans Merrem, 1820

Common Name: Puff adder.

Arabic Name: Haiya Al Nafasa.

Distribution: This species is the most common and widespread venomous snake in Africa. Its geographic range includes: South Africa, Namibia, Swaziland, Morocco, Saudi Arabia, Oman, and Yemen.

Distribution in Asir: Sites (1,9,10,12,16,17,18,20,21,22,23,26,30,32,36,39,40,42)

Habitat: It is found in all habitats except true deserts, rain forests and mountain tops. The preferred habitats for the species include open grassland, savanna, open woodlands and rocky outcrops.

Feeding: It feeds on small frogs, toads, small reptiles and small rodents but Schliech et al. (1996) found in its stomach a scorpion, a spider, termites and small beetles.

Mode of feeding: Chiefly nocturnal, but it is also found basking in the early morning (in spring and autumn).

Behavior: It is a usually nocturnal animal, hunting in ambush, relying in the immobility, but it is often met during the day, basking in the sun. After a cold night, an astonishing number of these reptilians may be met, all lying on the slopes or on the roads, and, even if terrestrial, they do not hesitate in climbing low shrubs especially when the soil is humid.

It is one of the most dangerous African serpents, but this assertion needs a clarification, so we will make a digression. The danger represented by a serpent to the man is not only in function of the strength of its venom, even if we have remarked that this is what strikes more many people.

Zoogeographical Distribution: Saharan.

Order Testudines

Suborder Pleurodira

Family Pelomedusidae

Genus Pelomedusa Gray, 1844

Pelomedusa subrufa (Bonnaterre, 1789)

Common name: Freshwater or helmeted turtle.

Distribution: Pelomedusa subrufa inhabits subtropical and tropical Africa from Ethiopia, southern Saudi-Arabia and Yemen, and the Sudan westward to Ghana, Senegal, Mali, Nigeria, and the Cameroons, and southward to Cape Provinces of South Africa. It is also known from many localities on Madagascar.

Distribution in Asir: Sites (6,8,11,25,34,34,35,41)

Habitat and ecology: The helmeted turtle is semi-aquatic, living in temporary marshes, creeks, and rain holes in the open country of Africa, generally south of the Sahara Desert. It is seldom found in heavily forested areas, but is known to occur 
from the coastal plain to upland savannahs of $3100 \mathrm{~m}$ elevation. Large populations sometimes inhabit the rain pools used as watering holes by African ungulates. The habitat requirements of Pelomedusa are apparently too dry for Pelusios, and for this reason Wood (1973) feels Pelomedusa has not been preserved as fossils as often as Pelusios, which inhabits permanent water bodies. When the temporary pools dry up, Pelomedusa buries itself in the mud bottoms until the next rainy season. Loveridge (1941) reported that South African individuals may hibernate out of water in soft soil or beneath leaves from May to August.

Ecology: It is omnivorous turtle feeds on mollusca, crustacea, and fish and also sea weeds.

Status: Threatened because of loss of nesting habitats, often caught incidentally in shrimp trawls while feeding on sea bottom. It is classified as Endangered by IUCN (2005).

\section{DISCUSSION}

The study was carried out in Asir region, located in the southwest of the country. Topography and biotic elements of the environment were described. The study area is one of the richest regions of the Kingdom of Saudi Arabia with animal biodiversity, where the region is characterized by the presence of a large group of wild animals that belong to different animal families. In this work, we studied biodiversity of herpetofauna which found in the region.

Amphibian diversity has been studied in Southwestern Saudi Arabia, yet no enough studies had been performed to provide basic information about the species life, especially the geographical distribution and dispersions. For the implementation of this study, a field study has been performed which considered as the main part of the work procedures used in this research.

This study recorded seven species of tailless amphibians (Anura), which belong to three families and 38 species of reptiles: 23 lizards belonging to six families and 14 species of snakes belonging to five families, in addition to one turtle species belongs to family Testudinidae.

The herpetofauna of Asir is similar to those of the other surrounding parts. The majority of species is represented in southwest Asia, northwest Ethiopian region, Palestine, Jordan and the Arabian peninsula. However, this study showed the expanding range of certain species that have been studied before such as Laudakia stellio (Eastern Egypt to Palestine), Scincus scincus (northeastern Africa) and Acanthodactylus boskianus (North Africa to Palestine). This may be attributed to the ability of some reptilian species to migrate to the neighboring areas in the same biogeographically region. The reptilian fauna of Asir represents the Afrotropic biogeographical region that includes Africa south of Sahara, and south Arabia which has the most varied fauna of all other regions.

Data is confirmed by reports of several other authors who obtained similar species for other surveys. Dekinesh (1991), Leviton et al. (1992), Michael et al. (1992), Hussein (1993). Hussein (1993) reported that Arabian region from northeast Africa to southwest Asia were characterized by an abundance of toads (family Bufonidae), geckos (family Gekkonidae), skinks (family Lacertidae), agamas (family Agamidae), monitors (family Varanidae) and colubrid snakes. The topography or the height and shape of the land, can play an important part in the distribution of species (Abrams, 1986; Chapman and Reiss, 1995). Even small changes in topography may be important. 
Of course, species can, and do, spread out from their evolutionary origin to reach new and distant regions even their continents don't join up, but this spread is limited by the extent and kinds of obstacles in their way (e.g. rivers, oceans, deserts and mountains). For example, in lowland on heavy clay soils the shallow depressions in the lowland floor becomes waterlogged after heavy rain and sometimes contain standing water, while the sides and tops of ridges remain relatively dry and the organisms are able to move freely from one place to other without any obstacles.

The fluctuations in climate and weather can also affect the distribution of species (Wilson and Willis, 1975; Ford, 1982) and this is due to a complex interaction of factors including the movement of areas of low and high pressure in the atmosphere which influences cloud cover, rainfall and temperature. A long-lived organism may experience a considerable variation in temperature, drought length and wind speed during its life cycle disrupted by "freak" weather conditions.

\section{REFERENCES}

Abrams, P. A. (1986): Reply, Trends in Ecology and Evolution, 1: 131-132.

Abuzinada, A.H., Robinson, E.R., Nader, I.A. \& Al Wetaid, Y.I. (2004): First Saudi Arabian National Report on the convention on Biological diversity. The National commission for Wildlife conservation and development, Riyadh. Riyadh. Saudi Arabia pp. 27-28.

Al-Sadoon, M.K. (1989): Survey of the reptilian fauna of the kingdom of Saudi Arabia I-The snake fauna of the central region J. King Saud Univ.1 A, Science (1): 53-69.

Al-Wailly, A.J. and Al-Uthman, H.S. (1971): "Some lizards from Central Saudi Arabia." Bull. Iraq Nat.Hist. Mus. 5(1): 39-42.

Anderson, J. (1898): Zoology of Egypt. Volume 1, Reptilia and Batrachia, Bernard Quaritch, London, $371 \mathrm{pp}$.

Balletto, E., Cherchi, M. and Gasperetti, J. (1985): Amphibians of the Arabian Peninsula. Fauna of Saudi Arabia, 9: 318-392.

Chapman, J.L. and Reiss, M.J. (1995): Ecology principles and applications. Cambridge Univ. Press, UK.

Corkill, N.L. (1932): The snakes of Iraq. - Journal of Bombay Natural History Society, 35: $552-572$.

Dekinesh, S.I., (1991): The reptilian fauna of Hail district, north of Saudi Arabia. J. Egypt. Ger. Soc. Zool., 5: 177-196.

Farag, A.A. and Banaja, A.A. (1980): Amphibians and reptiles from the western region of Saudi Arabia. Bull. Sci. K. A. U., 4: 5-29.

Ford, M.J. (1982): The changing climate: responses of the natural fauna and flora. George and Unwin Ltd., London.

Gasperetti, J. (1974): A Preliminary Sketch of the Snakes of the Arabian Peninsula. $J$. Saudi Nat. Hist. Soc., 12(1974), IV+72 pp.

Gasperetti, J. (1988): The Snakes of Arabia. Fauna of Saudi Arabia, 9: 169-450.

Herbert, H.J. (1981): Kouf National Park Wildife studies ACSAD, unpubal. 126 pp.

Hunter, M.L. (1996): Fundamentals of Conservation Biology. George G. Harrap and Co., Ltd., London, 207 pp.

Hussein, M.F. (1966): On the reptiles of Riyadh and its surroundings in Saudi Arabia. 5th Arab Sci. Congr. Baghdad.: 479-485

Hussein, H.K. (1993): Seasonal variation of daily activity times in gekkonid lizards inhabiting Burg El-Arab region, west of Alexandria. J. Egypt Ger. Soc. Zool., 11: 231-245.

IUCN (2004): 2004 IUCN Red List of the threatened species. www.redlist.org 
IUCN (2005): Global reptile assessment. Species accounts for Mediterranean species.

Lambert, M.R.K. (1984): Amphibians and reptiles. In: Cloudsley-Thompson (ed.) Sahara Desert, 205-227. Oxford: Pergamon Press. 348 pp.

Leviton, A.E. (1977a): A New Lytorhynchid Snake. J. Saudi Nat. Hist. Soc., 19: $16-25$.

Leviton, A.E. (1977b): On the Status of Natrix dubbiosi scortecci. J. Saudi Nat. Hist. Soc. 19: 26-29.

Leviton, A.E., Anderson, S., Adler, K. and Mimton, S. (1992): Handbook to Middle East amphibians and reptiles. Society for study of Amphibians and reptiles, Oxford, Ohio.

Loveridge, A. (1941): Revision of the African terrapin of the family Pelomedusidae. Bull. Mus. Comp. Zool. Harvard, 88: 467-524.

Mandaville, J.P. (1965): "Plants Eaten by Uromastix microlepis Blandford and other Notes on these Lizards in Eastern Arabia." J. Bombay Nat. Hist. Soc. 61(10) 161-163.

Mandaviile, J.P. (1967): The Hooded Malpolon moilensis Reuss and Notes on other Snakes of North-Eastern Arabia. J. Bombay Nat. Hist. Soc., 64(1): 115-117.

Marx, H. (1968): Checklist of the reptiles and amphibians of Egypt. Spec. Publ. U.S.A. Naval Med. Res. Unit No. 3, Cairo.

Mertens, R. (1960): The World of Amphibia and Reptilia. George G. Harrap and Co., Ltd., London, $207 \mathrm{pp}$.

Michael, M.I., Dekinesh, S.I. and Aly, A.H. (1992): The herpetofauna of north western coast of Egypt. J. Egypt. Ger. Soc. Zool., 8: 81-99.

Mittermeier, R.A., Carr, J.L., Swingland, I.R., Werner, T.B. and Mast, R.B. (1992): Conservation of Amphibians and Reptiles: 59-80. In: K. Adler (ed.), Herpetology: current research on the biology of amphibians and reptiles. Proceedings of the First World Congress of Herpetology. Society for the study of Amphibians and Reptiles, Oxford (Ohio).

Mulder, J. (2002): The thread snake, Leptotyphlops macrorhynchus (Reptilia: Leptotyphlopidae) as a presumed prey item for the racer Coluber rhodorachis (Reptilia: Colubridae). Zoology in the Middle-East, 26: 89-92.

Parker, H.W. (1933): Reptiles and amphibians, In: H. St. J.B. Philby, The Empty Quarter. London: Constable, 397-398.

Parker, H.W. (1938): Reptiles and Amphibians from Southern Hejaz. Ann. Mag. Nat. Hist. (Set. 11) 1(5): 481-492.

Saber, S.A. (1999): Gekkonidae of Egypt. Desert Inst. Bull. Egypt, 49(2): 337-368.

Saber, S.A., Bashandy, M.A., Kawashti, I.S. and Sadek, A.G. (1994): Feeding ecology of two sympatric lizards, Acanthodactylus boskianus asper (Lacertidae and Ptyodactylus guttatus (Gekkonidae) from Wadi Digla, Eastern Desert, Egypt. Bull. Zool. Soc. Egypt, 42: 187-206.

Saleh, M.A. (1997): Amphibians and reptiles of Egypt. Publication of the National Biodiversity Unit. No. 6. 234 pp.

Schlich, H.H., Kastle, W. and Kabisch, K. (1996): Amphibians and reptiles of North Africa. Scientific Books Germany.

Schmidt, K.P. (1941): Reptiles and Amphibia from Central Arabia. Field Mus. Nat. Hist. Zool. Ser. 24(16): 161-165.

Wilson, E.O. and Willis, E.O. (1975): Applied biogeography. In: Cody, M.L. \& Diamond, J.M. (Eds), Ecology and Evolution of Communities. Harvard Univ. Press. Cambridge, pp: 522-534.

Wood, R.C. (1973): A possible correlation between the ecology of living African pelomedusid turtles and their relative abundance in the fossil record. Copeia 1973: 627-629. 


\section{Class Amphibia}

\section{List of Taxa}

Family Bufonidae: Bufo arabicus, B. dhufarensis, B. tihamicus, B. v. viridis

Family Hylidae: Hyla savignyi

Family Ranidae: Euphlyctis ehrenbergii, Rana ridibunda

\section{Class Reptilia}

Order Squamata

Suborder Sauria

Family Agamidae: Laudakia s. stellio, Pseudotrapelus sinaitus, Trapelus mutabillis, T. p. pallidus, Uromastyx aegyptia microlepis

Family Amphisbaenidae: Diplometopon zarudnyi

Family Chamaeleontidae: Chamaeleo c. Chamaeleon

Family Gekkonidae: Gymnodactylus scaber, Hemidactylus flaviviridis, H. turcicus, Ptyodactylus $h$. hasselquistii, Stenodactylus sthenodactylus, Tarentola a. annularis, Tarentola m. mauritanica, Tropiocolotes tripolitanus

Family Lacertidae: Acanthodactylus boskianus asper, A. s. scutellatus, Mesalina guttulata

Family Scincidae: Chalcides o. ocellatus, Eumeces schneiderii, Scincus s. scincus, Trachylepis vittata

Family Varanidae: Varanus g. griseus

Suborder Ophidia

Family Colubridae: Lytorhynchus diadema, Malpolon moilensis, Platyceps elegantissimus, P. rhodorhachis, P. rogersi, Psammophis s. Schokari, Spalerosophis diadema cliffordi

Family Elapidae: Naja haje arabica

Family Viperidae: Bitis a. arietans, Cerastes c. gasperetti, Echis carinatus, Echis coloratus

Family Typhlopidae: Leptotyphlops macrorhynchus, Ramphotyphlops braminus Order Testudines

Family Pelomedusidae: Pelomedusa subrufa 


\title{
ARABIC SUMMARY
}

دراسات بيئية على التنوع الحيوي لفونة البرمائيات والزواحف فى منطقة عسير "المملكة العربية السعودية"

\author{
مصطقى فتحي مسعود * ـ أحمد على أحمد عسيري

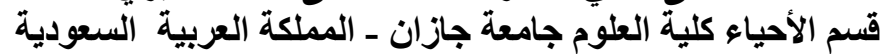

* Email: m_f_masood@yahoo.com

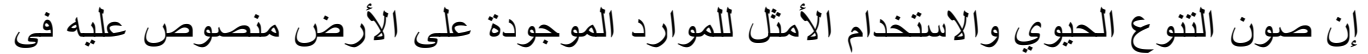

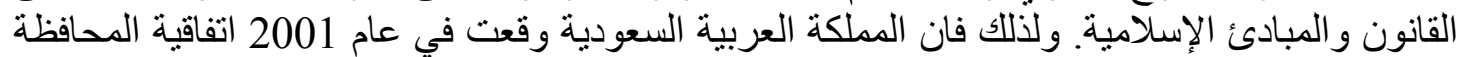

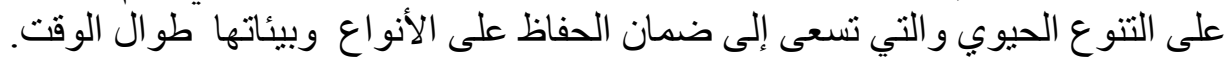

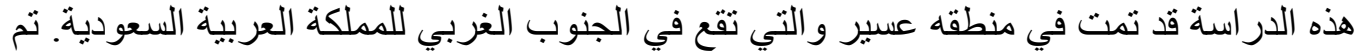
وصف العو امل الطبو غر افية و المكونات الحية في تللك البيئة. منطقة الدراسة والئة واحدة من أغنى مناطق

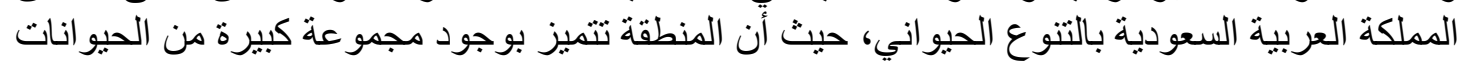

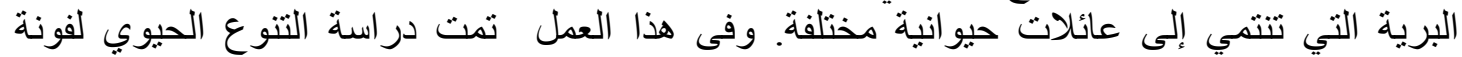

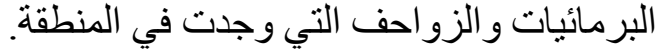

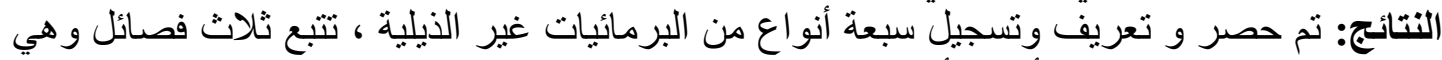

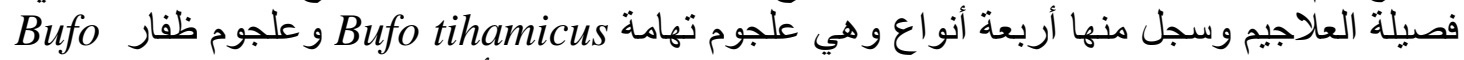
dhufarensis و العلجوم العربي Bufo arabicus و العلجوم الأخضر Bufo viridis.

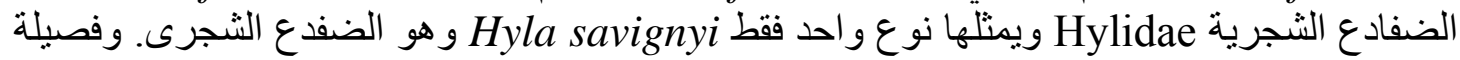

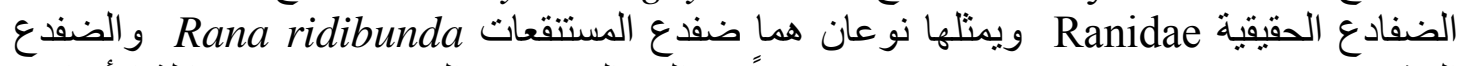

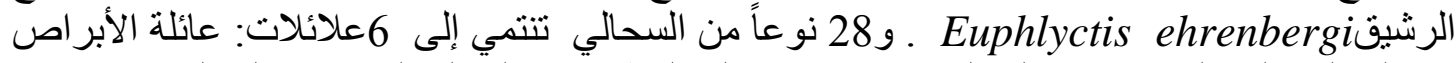

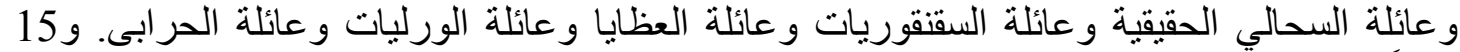

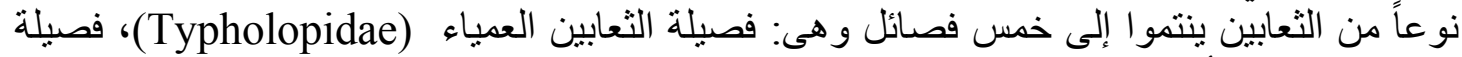

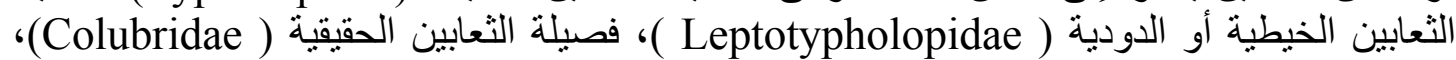
فصيلة الأيلابيدى أو الكوبريات (Elapidae)، فصيلة الفيبريدى "الحيات" (Viperidae). ونوع واحين (احد فقط من السلاحف ينتمي إلى فصيلة السلاحف (Testudinidae).

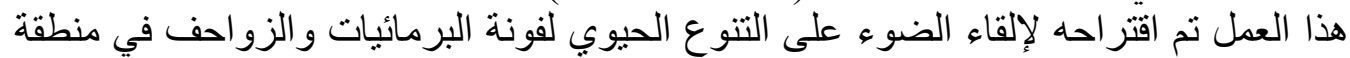

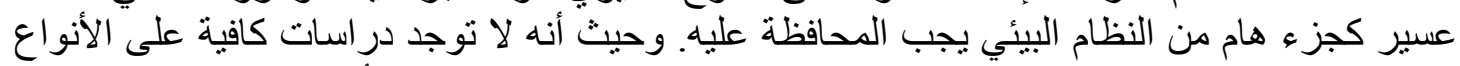
الحيوانية الموجودة في المنطقة، جاءت هذه الدراسة للتعرف على التنوع الأحيائي، ولتحديد التركيب

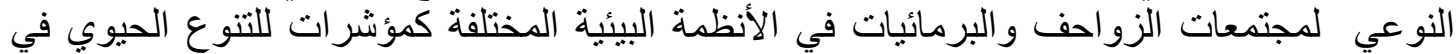
منطقة الدر اسة وكذلك جاءت لاقتر اح بعض الخطط و الأساليب لتحديد مدى وفرة هذه الأنو العاع. 